\title{
ROOSEVELT CONTRA HOOVER: A “GUERRA” DO INVERNO DE 1932-1933 E O DESENVOLVIMENTO DO NEW DEAL
}

\author{
Roosevelt versus Hoover: the winter "war" of 1932-1933 \\ and the development of the New Deal
}

\section{Lucas Maia Felippe Bacas*}

Resenha de: RAUCHWAY, Eric. Winter war: Hoover, Roosevelt and the first clash over the New Deal. New York: Basic Books, 2018, 294 p.

Resumo: A seguinte resenha analisa a obra Winter war: Hoover, Roosevelt and the first clash over the New Deal do historiador norte-americano Eric Rauchway. A obra foi concebida a partir de uma investigação sobre os meses entre a eleição do presidente democrata Franklin Delano Roosevelt em novembro de 1932 e sua posse em março de 1933. Trata-se de uma tentativa de examinar as disputas políticas entre Roosevelt e seu oponente, o então presidente republicano Herbert Hoover.

Palavras-chave: Grande Depressão, História dos Estados Unidos, New Deal

Abstract: The following review analyze the book Winter war: Hoover, Roosevelt and the first clash over the New Deal from the American historian Eric Rauchway. The work has been conceived through the investigation of the months between the election of the Democrat president Franklin Delano Roosevelt in November 1932 and his Inauguration Day in March 1933. It attempts to examine the political disputes between Roosevelt and his opponent, the Republican president Herbert Hoover.

Keywords: Great Depression, American History, New Deal

O New Deal, programa de amplas reformas da década de 1930 capitaneado pelo presidente democrata Franklin Delano Roosevelt (FDR), se faz presente nos debates políticos dos Estados Unidos até os dias de hoje. Sem dúvidas, o empreendimento reformista se consolidou como uma tradição política norte-americana que mobiliza o discurso de progressistas - como pudemos ver recentemente com a proposta de um “Green New Deal” por políticos do Partido Democrata.

Assim, diante do contínuo olhar dos norte-americanos acerca do tema, o historiador e professor da University of California, Eric Rauchway, oferece uma nova perspectiva a respeito do New Deal, desta vez focando nas disputas que se passaram antes da presidência de Roosevelt (19331945). O democrata, que fora eleito em novembro de 1932, esperou quase quatro meses para assumir o cargo de presidente dos Estados Unidos, ao passo que o republicano Herbert Hoover (1929-1933), então ocupando o posto, iniciou uma campanha de bastidores que objetivava esvaziar o "novo acordo" prometido por Roosevelt durante a campanha.

\footnotetext{
* Mestrando pelo Programa de Pós-Graduação em História Social da Universidade de São Paulo (USP). E-mail: lucas.bacas@gmail.com

1 FRIEDMAN, Lisa. What is the Green New Deal? A Climate Proposal, Explained. The New York Times, New York, 21 fev. 2019. Disponível em: <https://www.nytimes.com/2019/02/21/climate/green-new-dealquestions-answers.html>. Acesso: 28 out. 2019.
} 
O título do livro faz referência aos meses entre a eleição presidencial e a posse do novo presidente, que circunscrevem o fim do outono e o período de inverno no país, quando uma "guerra" política nos bastidores fora travada entre Roosevelt e Hoover. Fazendo uso de uma série de correspondências e documentos pessoais desses homens e de assessores próximos, Rauchway examinou suas fontes na tentativa de analisar a concepção do New Deal nos meses que antecederam a posse presidencial em março de 1933.

Para o autor, diferentemente do que parte da historiografia argumenta, as políticas reformistas de Roosevelt não poderiam ser vistas como resultado de uma "atitude" e não um programa devidamente planejado pelo presidente, como afirmou Frances Perkins - Secretária do Trabalho durante o New Deal - em seu relato autobiográfico nos anos 1940. Rauchway afirma que o democrata já possuía posições consolidadas em uma série de tópicos antes mesmo de ascender ao cargo em 1933 e, principalmente, um objetivo claro: derrotar o espectro do fascismo e a descrença na democracia que percebia se fortalecendo no país a partir da Grande Depressão iniciada em 1929.

Nesse tópico, ele propõe que a essência do programa partiu do próprio FDR e rebate autores que contestam a noção de que o New Deal fora concebido durante a campanha eleitoral por Roosevelt: "Perkins pode ter sido uma grande Secretária do Trabalho, mas ela era uma péssima historiadora: nenhuma palavra de suas afirmações é real. Na verdade é difícil pensar em algum aspecto importante do New Deal no qual Roosevelt não tenha claramente se comprometido antes de ascender ao cargo. Ele tinha um plano, ele manteve conferências com lideranças partidárias para resolver detalhes e chegar em acordos e ele até possuía uma posição teórica bem estabelecida". (RAUCHWAY, 2018, p.15-16)

Um dos principais argumentos que o autor usa para comprovar sua tese é o de que Hoover - que teria identificado as particularidades do programa do democrata - tentou em uma série de cartas, telegramas e até mesmo encontros, dissuadir o recém-eleito Roosevelt a se comprometer com propostas reformistas que envolviam o aumento da atuação do Estado na economia. Entre elas, a diminuição de tarifas exportadoras, serviços de iluminação públicos, alívio econômico para os desempregados e a promoção de um arrojado plano de obras públicas.

Aos olhos do republicano, o New Deal era particularmente "estrangeiro" e alheio às tradições norte-americanas de governo e Roosevelt era visto como um "progressista extremo". Segundo o autor, Hoover tinha plenas convicções de que o empreendimento de FDR tornaria os Estados Unidos um país comunista. Portanto, ele argumentava que Roosevelt deveria seguir as diretrizes políticas consolidadas por seu governo, que envolviam, entre outras coisas, concepções de individualismo e de mínima interferência estatal. Para Hoover, o país corria sérios riscos ao abrir mão do laissez-faire.

É nesse cenário que Rauchway nos mostra os debates daquele inverno em oito capítulos, examinando as disputas entre ideias progressistas e conservadoras na condução das políticas norteamericanas. Seis desses capítulos enfatizam alguns assuntos específicos, entre eles: política exterior e o comprometimento do New Deal com o combate ao nazifascismo e ao expansionismo japonês, soluções para a crise no campo e na indústria, o posicionamento de Roosevelt e de Hoover acerca dos direitos civis para os afro-americanos e, por fim, os debates econômicos do período.

Esse último tópico, inclusive, é percebido pelo autor como responsável por sedimentar os posicionamentos dos partidos Democrata e Republicano nas disputas em torno do papel do Estado na economia até os dias de hoje. Sem dúvidas, Rauchway têm um claro enfoque em Winter war: observar como o conflito de bastidores entre Roosevelt e Hoover ditou diferentes posicionamentos de progressistas e conservadores nos Estados Unidos que, a despeito de mudanças pontuais, 
beberam da essência das disputas dos anos 1930.

Rauchway se desdobrou em sua tarefa de inserir o leitor no contexto da Grande Depressão - o eixo das disputas da década - e de que forma atores de posicionamentos distintos supunham ter uma solução para os problemas que enfrentavam. Ele não tem dúvidas de que o New Deal foi mais do que um mero programa de políticas de "tentativa e erro" capitaneadas por um presidente "pragmático" e determinado a "experimentar" soluções. O autor também reitera o papel dos anos 1930 como um período de reconfiguração no seio dos dois grandes partidos nos Estados Unidos. De acordo com Rauchway, Hoover via os políticos progressistas de dentro do Partido Republicano como "traidores da tradição de liberdade norte-americana". Ao mesmo tempo, ele já reparava no potencial eleitoral do voto branco sulista que almejava restringir os direitos civis dos afro-americanos, até então uma sólida base para os democratas (Ibid., 2018, p. 91, 111).

Ao destacar o pensamento de Hoover, o autor contribui para a historiografia do New Deal ao analisar o desenvolvimento do que chamou de "hooverismo": uma força política conservadora e contrária ao New Deal que passou aos poucos a dominar a visão de governo do Partido Republicano. Em sua tentativa de combater o projeto de Roosevelt, Hoover alicerçou as bases para o conservadorismo dos republicanos, que mesmo nos dias de hoje combatem políticas reformistas do democratas reputando-as como socialistas ou comunistas. ${ }^{2}$ Ainda que tenha ocorrido no inverno entre os anos de 1932 e 1933, outra contribuição da obra de Rauchway é nos permitir visualizar como grande parte desses debates que antecederam o New Deal reverberam nas disputas dos de hoje e mobilizam diferentes segmentos políticos nos Estados Unidos.

\section{- Links consultados}

Website do The New York Times

FRIEDMAN, Lisa. What is the Green New Deal? A Climate Proposal, Explained. The New York Times, New York, 21 fev. 2019. Disponível em: <https://www.nytimes.com/2019/02/21/climate/greennew-deal-questions-answers.html>. Acesso: 28 out. 2019.

KARNI, Annie. GOODNOUGH, Abby. Trump Uses Health Care Announcement to Brand Democrats as Socialists. The New York Times, New York, 3 out. 2019. Disponível em: <https://www.nytimes.com/2019/10/03/us/politics/medicare-executive-order.html>. Acesso: 28 out. 2019.

Resenha recebida em: 30/10/2019

Resenha aceita em: 08/01/2020

\footnotetext{
2 KARNI, Annie. GOODNOUGH, Abby. Trump Uses Health Care Announcement to Brand Democrats as Socialists. The New York Times, New York, 3 out. 2019. Disponível em: <https://www.nytimes.com/2019/10/ 03/us/politics/medicare-executive-order.html>. Acesso: 28 out. 2019.
} 